\title{
Heilbrigðiskerfi á krossgötum
}

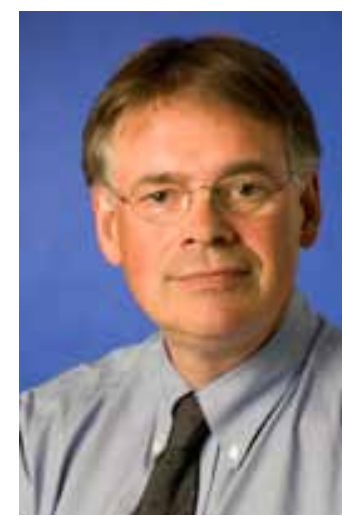

Steinn Jónsson

steinnj@landspitali.is

Höfundur er lungnalæknir á Landspítala og formaður Læknafélags Reykjavíkur.

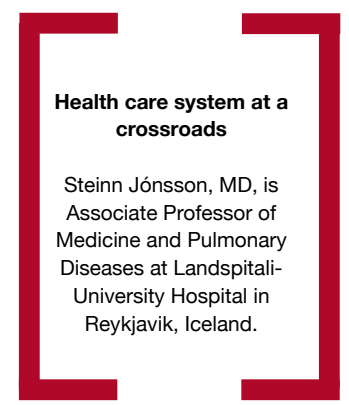

Рað er kunnara en frá purfi að segja að margvísleg vandamál steðja nú að heilbrigðispjónustunni. Á peim fáu árum sem liðin eru frá efnahagshruninu hefur Ísland tapað samkeppnishæfni gagnvart útlöndum. Læknar starfa á alpjóðlegum vinnumarkaði og víða í nágrannalöndunum er skortur á vel menntuðum læknum og há laun í boði. Petta er pegar farið að hafa áhrif hér á landi og læknaskortur er farinn að verða tilfinnanlegur, bæði í heilsugæslunni og meðal yngri lækna á Landspítala. Kjör lækna á Íslandi hafa rýrnað um meira en 50\% ef miðað er við nágrannalönd. Viðhorfsbreyting hefur átt sér stað meðal yngra fólks á síðustu áratugum. Раð sættir sig ekki lengur við óhóflegt vinnuálag sem kemur niður á frítíma og fjölskyldulífi.

Frá pví sjúkrahúsin í Reykjavík voru sameinuð árið 2000 hefur verið óopinbert ráðningabann gagnvart sérfræðilæknum. Mikið aðhald hefur einkennt allan rekstur í heilbrigðiskerfinu, bæði á góðæristímanum og eftir efnahagshrunið. Lítil sem engin nýliðun hefur átt sér stað meðal sérfræðilækna á undanförnum árum. Er pað mikið áhyggjuefni. Ungir sérfræðilæknar hafa jafnan komið til Íslands með nýja pekkingu og gegnt mikilvægu hlutverki við próun heilbrigðispjónustu hér á landi. Víða erlendis sinna læknar á efri stigum sérfræðináms og ungir sérfræðilæknar mikilvægum störfum en á Íslandi vantar pessa hópa nánast alveg. Pað er pví mikilvægt verkefni að byggja upp framhaldsnám í læknisfræði hér á landi eftir pví sem kostur er.

Deila framkvæmdastjórnar Landspítala við unglækna vegna vaktakerfis hefur haft slæm áhrif á starfsanda almennra lækna ef marka má nýlega viðhorfskönnun meðal starfsfólks. Framkvæmdastjórnin hugðist spara með nýju vaktakerfi sem jók vinnutíma en ekki laun. Félag almennra lækna stóð einhuga gegn peim áformum með vinnutímatilskipun EES-samningsins að vopni. Sérfræðilæknar gáfust upp við að manna vaktir almennra lækna eftir eina viku í apríl 2010. Eftir langar samningaviðræður var ákveðið að vaktakerfi Landspítala skyldi uppfylla vinnutímatilskipun EES. Pessi niðurstaða verður til pess að fleiri lækna parf til pess að manna vaktakerfin og dagvinnuna á spítalanum í framtíðinni. Viðhorf ungra lækna til starfa á Landspítala hefur versnað og mátti síst við pví í viðbót við önnur aðsteðjandi vandamál.

раð er athyglisvert að skoða hvernig í pottinn er búið við stjórnun Landspítala. Forstjórinn er ráðinn af ráðherra og ábyrgur gagnvart honum og ríkisstjórninni. Framkvæmdastjórar sviðanna sem hafa mikla rekstrarábyrgð eru ráðnir af forstjóranum og ábyrgir gagnvart honum. Forstjórinn hefur krafist pess að framkvæmdastjórarnir segi sig úr fagfélögum, svo sem Læknafélagi Íslands, til pess að geta sinnt skyldustörfum sínum í framkvæmdastjórninni. Yfirlæknar hafa verið beðnir að segja sig úr samninganefndum vegna hugsanlegra hagsmunaárekstra. Petta nær ekki nokkurri átt. Hvaða hagsmunaárekstra er verið að koma í veg fyrir með pessari kröfu? Erum við ekki öll að vinna saman að pví að byggja upp háskólaspítala og varðveita eitt besta heilbrigðiskerfi í heimi? Er skynsamlegt af stjórnvöldum að stilla framkvæmdastjórninni upp með pessum hætti?

Margt bendir til pess að innan skamms geti Landspítali lent í verulegum vandræðum í mikilvægum sérgreinum vegna skorts á almennum læknum og sérfræðilæknum. Kjaraskerðingarstefnan og niðurskurðurinn eru farin að hafa veruleg áhrif á vinnuprek og hugarfar margra lykilaðila innan spítalans. Рað er ekki seinna vænna að stjórnvöld fari að gera sér grein fyrir pessum vanda og grípa til aðgerða.

раð fyrsta sem menn purfa að skilja er að fyrsta flokks heilbrigðiskerfi er byggt upp af fagfólki og til pess að varðveita pann auð parf að rækta hann eins og allt annað sem vel á að virka. Frekari kjaraskerðing, aukið vinnuálag og ráðningabann eru ekki leiðir að pví marki. Stjórnvöld verða að skoða mjög vandlega hvernig pau hyggjast umgangast fagfólkið í heilbrigðispjónustunni ef ekki á að stefna í algert óefni pegar á pessu ári. Heilbrigðiskerfið stendur að pessu leyti á krossgötum og forystumönnum lækna og framkvæmdastjórn Landspítala ber skylda til að kynna stjórnvöldum og almenningi hvert stefnir. 